\title{
Effect of Entrepreneurial Self-Efficacy on the Entrepreneurial Intentions of Students at a University in Hainan Province in China: Taking Social Support as a Moderator
}

\author{
Li-Yu Wang \\ Hainan Tropical Ocean University \\ Sanya, China \\ Dhurakij Pundit University \\ Bangkok, Thailand \\ Jian-Hao Huang \\ Dhurakij Pundit University \\ Bankok, Thailand
}

\begin{abstract}
This study discussed the relationship among university students' entrepreneurial self-efficacy, social support, and entrepreneurial intentions. In 2018, the present study recruited 870 students from a public university in Hainan Province, China. This university offered entrepreneurial practice courses, students from this university had been performing exceptionally in entrepreneurial competitions, and its graduates showcased outstanding entrepreneurship, indicating this university a paradigm of entrepreneurial education. Entrepreneurial self-efficacy scale, perceived social support scale, and entrepreneurial intention scale were employed to survey the students. Specifically, the effect of university students' entrepreneurial self-efficacy on entrepreneurial intention and the moderation of social support on said effect were explored. The following results were obtained: (a) entrepreneurial self-efficacy significantly and positively predicted entrepreneurial intentions, and (b) social support positively moderated the effect of entrepreneurial self-efficacy on entrepreneurial intentions. This study provided a theoretical and practical reference for improving the entrepreneurial intentions of university students.
\end{abstract}

Keywords: University students' entrepreneurship; entrepreneurial self-efficacy; social support; entrepreneurial intentions; moderator.

\section{Introduction}

Entrepreneurship refers to the process of starting and managing a new business in the pursuit of profit and economic development (Carland, Hoy, Boulton, \& Carland, 1984). Entrepreneurship promotes the improvement and economic 
growth of a country, accelerates economic structural adjustment, reduces economic inequality between regions, alleviates unemployment, ethnic tensions, and poverty, and ensures satisfactory corporate development (Bosma, Acs, Autio, Coduras, \& Levie, 2009). University students' entrepreneurship promotes job opportunities and positions, mitigates employment pressure (particularly for university graduates), and facilitates economic growth as well as technological innovation and transformation (Katz, Hanke, Maidment, Weaver, \& Alpi, 2016).

Only entrepreneurs with considerable entrepreneurial intentions are capable of entrepreneurship (Krueger \& Brazeal, 1994). Bird (1988) contended that entrepreneurial intentions are psychological states in which entrepreneurs invest their concentration, energy, and actions to achieve specific goals and that entrepreneurial intentions are required for individual and social factors to affect entrepreneurship. Krueger (1993) reported that entrepreneurial self-efficacy was a key factor influencing entrepreneurial intentions. Entrepreneurial self-efficacy refers to individuals' confidence in their entrepreneurial capabilities (Brice \& Spencer, 2007). Boyd and Vozikis (1994) combined entrepreneurial theories with the concept of self-efficacy proposed by Bandura (1977), defining entrepreneurial self-efficacy as individuals' confidence in and capability to assess their entrepreneurial capacity, with the degrees of entrepreneurial self-efficacy differing among individuals. Kickul, Gundry, Barbosa, and Whitcanack (2009) discovered that students' self-confidence and entrepreneurial knowledge were positively associated with their entrepreneurial thinking and the feasibility of their entrepreneurial ideas. Therefore, university students with high self-efficacy are highly confident in their chances of successful entrepreneurship.

Liao and Welsch (2003) indicated that social support factors such as capital, information, and the encouragement and understanding of family and friends facilitated successful entrepreneurship. Cohen and Mackay (1984) observed that social support provided help and care to individuals in a low psychological state and served as an external factor through which individuals to relieve emotional difficulties. Lüthje and Franke (2003) maintained that school, family, and social environments adverse to entrepreneurship inhibit entrepreneurial intentions, whereas those favorable to it enhance entrepreneurial intentions. Studies have reported that social support moderated the relationships between job stress and burnout, between self-esteem and quality of life, and between financial stress and psychological wellbeing (Sun et al., 2017; Viseu et al., 2018; Xu, Wang, \& Li, 2013). Consequently, this study inferred that social support moderated the effect of entrepreneurial self-efficacy on entrepreneurial intentions.

In 2010, the Ministry of Education of the People's Republic of China announced 
its Statements on Promoting Innovative Entrepreneurial Education in Universities and Autonomous Entrepreneurship in University Students. In 2015, the General Office of the State Council published its Statements on Furthering Reforms in Innovative Entrepreneurial Education in Universities to encourage university students' entrepreneurship and promote entrepreneurship as China's national strategy on future economic development (Shan, Jia, Zheng, \& Xu, 2018). Hainan Province, a tropical island located to the south of China, is a provincial administrative region of China. The Hainan provincial government has collaborated with universities and enterprises to develop a university entrepreneurship service system. This system ensures the stable development of university entrepreneurial education in Hainan Province and establishes a satisfactory entrepreneurial environment. Because Hainan Province possesses relatively mature entrepreneurial education and entrepreneurship promotion strategies for university students in China, this study selected university students in Hainan Province as the research participants. Specifically, the participants were students of a public university in Hainan Province whose graduates have shown outstanding entrepreneurship.

Recent studies have focused on the effect of education levels on entrepreneurial intentions (Passaro, Quinto, \& Thomas, 2018). Some have examined entrepreneurial intentions from the perspectives of online platforms and university environments (Barral, Ribeiro, \& Canever, 2018; Lee, Lee, \& Gim, 2018; Oftedal, Iakovleva, \& Foss, 2018). Previous studies have found that entrepreneurial self-efficacy has significantly and positively predicted entrepreneurial intentions (Fan \& Wang, 2004; Naktiyok, Karabey, \& Gulluce, 2010; Qiao \& Huang, 2019). Furthermore, Zhao, Seibert, and Hills (2005) contended that entrepreneurial self-efficacy serve as a complete mediator of the effect of entrepreneurial risks on entrepreneurial intentions. However, there are few studies on the moderating effect of social support on the relationship between entrepreneurial self-efficacy and entrepreneurial intentions. Thereby, this study explored the effect of university students' entrepreneurial self-efficacy on entrepreneurial intentions as well as the moderation of said effect by social support.

\section{Literature Review}

The following is an introduction to the theoretical basis of this research. Secondly, it discusses entrepreneurial intentions, entrepreneurial self-efficacy, social support and measurement tools in sequence. Finally, the relationship between entrepreneurial self-efficacy, entrepreneurial intentions and social support are discussed. 


\subsection{Research Theories}

Bandura (1977) regarded triadic reciprocal determinism as the core of social cognitive theory. According to Bandura (1989), triadic reciprocal determinism indicates that individual, environmental, and behavioral factors are independent from but interact with one another. The effect of environmental factors on behavioral factors is latent and becomes substantial only when environmental factors are combined with individual factors and triggered by corresponding behaviors. Moreover, individual and environmental factors are reciprocally determined by each other, and environmental factors positively affect individual factors. Thus, environmental, individual, and behavioral factors are reciprocally determined by one another. In the present study, entrepreneurial self-efficacy was considered an individual factor, social support was determined to be an environmental factor, and entrepreneurial intentions were defined as a behavioral factor. The combined effect of entrepreneurial self-efficacy and social support on entrepreneurial intentions was examined. On the basis of the research objectives and relevant theories, this study proposed a feasible research framework.

\subsection{Entrepreneurial Intentions}

Lumpkin and Dess (2001) defined entrepreneurial intentions as dynamic processes aimed at group innovations, group-level strategy-making processes, and the intentions and behaviors of key people in a group. According to Thompson, Jones-Evans, and Kwong (2009), entrepreneurial intentions are a form of determination for entrepreneurship, and when an individual forms an entrepreneurial intention, he or she develops cognition for entrepreneurial activities; people with entrepreneurial intentions are distinguishable from those who simply possess entrepreneurial traits because people with entrepreneurial intentions perform entrepreneurship at specific times and nodes. In the present study, entrepreneurial intentions were defined as individuals' entrepreneurial knowledge and their psychological feedback concerning their own entrepreneurial capabilities. Fishbein and Ajzen (1975) discovered that individuals' behaviors can be explained and predicted through their behavioral intentions. When individuals are caught in an uncertain situation during entrepreneurship, they continue to seek future opportunities to achieve their goals; this consciousness is called an entrepreneurial intention (Mintzberg, 1973).

Phan, Wong, and Wang (2002) divided entrepreneurial intentions into three dimensions, namely entrepreneurial planning, individual proactiveness to learn about entrepreneurial procedure, and entrepreneurial possibilities. Liñán and Chen (2009) developed a simple entrepreneurial intention scale with a total of six items and a Cronbach's a of 0.943; the short scale and its high reliability render it applicable for tests on university students. Therefore, the present study 
adopted this entrepreneurial intention scale to survey university students.

\subsection{Entrepreneurial Self-Efficacy}

Chen, Greene, and Crick (1998) defined entrepreneurial self-efficacy as entrepreneurs' self-confidence in being able to fulfill their roles and accomplish entrepreneurial tasks, which is critical to determining whether to practice entrepreneurship. Because entrepreneurial self-efficacy compensates for insufficient entrepreneurial capabilities and knowledge, enabling entrepreneurs to adapt to unknown entrepreneurial environments, understanding entrepreneurial self-efficacy is crucial for upcoming entrepreneurs (Engel, Dimitrova, Khapova, \& Elfring, 2014). The present study defined entrepreneurial self-efficacy as entrepreneurs' level of determination and self-confidence in their entrepreneurship. Entrepreneurial self-efficacy is critical to individuals' likelihood of becoming successful entrepreneurs, involves their self-confidence in and assessment of their entrepreneurial activities, and is distinguishable in its levels (Boyd \& Vozikis, 1994).

Newman, Obschonka, Schwarz, Cohen, and Nielsen (2018) conducted a systematic review on scales devised to measure entrepreneurial self-efficacy, revealing that the multidimensional scale devised by Chen et al. (1998) was the most widely applied of all the scales reviewed. The scale contains 22 items encompassing marketing, innovation, management, risks, and finance. Han and $\mathrm{Fu}$ (2009) conducted a questionnaire survey and interviews with university teachers experienced in entrepreneurial education and divided entrepreneurial self-efficacy into two dimensions, namely basic self-efficacy and self-control efficacy. The questionnaire items on basic self-efficacy comprise entrepreneurial goal achievement, leadership, maintaining one's innovation capacity, self-confidence in entrepreneurship, interpersonal coordination and communication, and continual learning. Those on self-control efficacy focus on individuals' senses of self-doubt, inability, and lack of perseverance. Referencing the questionnaire dimensions and items proposed by Chen et al. (1998) and Han and Fu (2009), Niu (2017) established a 16-item entrepreneurial self-efficacy scale aimed at university students. This scale focuses on four dimensions: self-efficacy on innovation, opportunity identification, relationship coordination, and risk taking. The present study adopted this entrepreneurial self-efficacy scale to survey university students.

\subsection{Social Support}

Thoits (1986) defined social support as help provided to individuals by people playing critical roles in their lives to overcome difficulties and anxiety, such as stress relief, psychological counseling, and material support. According to Malecki and Demaray (2002), social support is an act of help that enables an 
individual to overcome difficulties and pressure in undesirable situations. In the present study, social support was defined as an external force that enables individuals to solve personal problems and improve their psychological health; individuals perceive social support at specific times and occasions and react to it differently according to their understanding and acceptance of that support.

Cobb (1976) defined social support as a type of message that enables individuals to stabilize their emotions when facing developmental or emotional difficulties. Thoits (1986) identified the following positive effects of social support: (a) individuals acquired a positive and firm mindset after perceiving respect, encouragement, and care from others, thereby improving their psychological stability; (b) individuals became motivated to solve problems, reduce their anxiety, and expand their scope of knowledge after acquiring the experience and knowledge required to solve problems from others; and (c) individuals could solve financial problems and improve their living environments after receiving material and labor support.

Sarason and Johnson (1981) developed a social support questionnaire that encompasses two dimensions, namely the quantity of social support, which refers to individuals' level of psychological desire to receive help and rely on others, and the quality of social support, which alludes to individuals' satisfaction with the received social support. Barrera (1986) referred to perceived social support as individuals' perception of support from others in their social interactions. Zimet, Dahlem, Zimet, and Farley (1998) created a perceived social support scale consisting of three dimensions, namely family, friend, and other support. The scale was revised by Yan and Zheng (2006) for use on university students; the revised version consists of 12 items encompassing three dimensions, namely family, friend, and other support (e.g., from teachers, schoolmates, and relatives). The present study adopted this revised version to survey university students.

\subsection{Relationship between Entrepreneurial Self-Efficacy and Entrepreneurial Intentions}

Fan and Wang (2004) pointed out that if an individual has a high sense of self-efficacy, the higher the entrepreneurial intention. Zhao et al. (2005) observed that individuals with higher entrepreneurial self-efficacy were more confident in their ability to start their own business and more likely to become involved in entrepreneurship in the future. Furthermore, Urban (2006) reported that entrepreneurial self-efficacy affected entrepreneurial intentions significantly. Kickul et al. (2009) revealed that students' self-confidence in and concepts regarding entrepreneurship were positively associated with their entrepreneurial thinking and the feasibility of their entrepreneurial ideas; specifically, higher self-efficacy led them to more positively believe in their 
ability to succeed at entrepreneurship. Naktiyok, Karabey, and Gulluce (2010) examined the relationship between entrepreneurial self-efficacy and entrepreneurial intentions in Turkish culture with 245 undergraduates from a Turkish university as a sample. The results show that entrepreneurial self-efficacy has a strong effect on entrepreneurial intention. Qiao and Huang (2019) investigated 1039 college students from a university in Shandong province, China, and the results showed that entrepreneurial self-efficacy of college student significantly and positively affected entrepreneurial intentions. Hence, entrepreneurial self-efficacy facilitates entrepreneurial intentions in university students. Therefore, this study proposed the following hypothesis. H1: Entrepreneurial self-efficacy significantly and positively predicts university students' entrepreneurial intentions.

\subsection{Moderating Effect of Social Support on the Relationship between Entrepreneurial Self-Efficacy and Entrepreneurial Intentions}

Forbes (2005) contended that individuals' seeking of external funding and support substantially affect their psychological reactions to the receipt of the support because the seeking and receiving of external support enhance their confidence in entrepreneurship and further motivate them to practice entrepreneurship. Previous researches results have shown that the positive relationship between University support and the entrepreneurial intention were supported (Coduras, Urbano, Rojas, \& Martínez, 2008; Gelard \& Saleh, 2011; Nasiru, Keat, \& Bhatti, 2015). University students with higher social support exhibit higher entrepreneurial intentions (Abebe, Gangadharan, \& Sutanonpaiboon, 2014). Shiri, Mohammadi, and Hosseini (2012) have shown that social support can change expectations of entrepreneurial intentions and promote students to engage in entrepreneurship. Xu et al. (2013) have reported that social support effectively mitigated the effect of job stress on university teachers' job burnout. Moreover, social support moderates the relationship between self-esteem and quality of life; strengthening social support can improve the quality of life of older adults with low self-esteem (Sun et al., 2017). In addition, social support was reported to mitigate the negative effect of financial stress on psychological health; individuals faced with financial stress become optimistic and have their psychological state stabilized if they receive social support, such as spiritual or material support from families, colleagues, and friends (Viseu et al., 2018). Accordingly, social support is an effective moderator. In the present study, social support was inferred to strengthen the relationship between university students' entrepreneurial self-efficacy and their entrepreneurial intentions. This study proposed the following hypothesis. H2: Social support positively moderates the relationship between university students' entrepreneurial self-efficacy and their entrepreneurial intentions. 


\section{Research Method}

The following is a description of the research framework, research participants, research instruments (entrepreneurial self-efficacy scale, perceived social support scale, entrepreneurial intention scale), and statistical analysis method.

\subsection{Research Framework}

A research framework was constructed according to the aforementioned hypotheses (Figure 1).

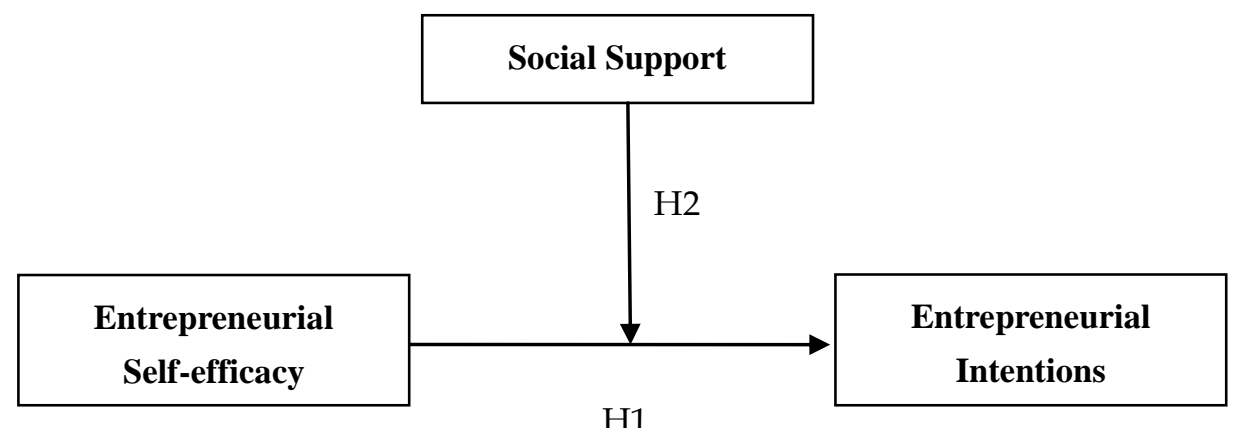

Figure 1. Research framework.

\subsection{Research Participants}

The participants were students at a university in Hainan Province specializing in oceanography, who were recruited through convenience sampling in October 2018. From 2015 to 2017, 507 students from the university dedicated themselves to entrepreneurship; a total of 171 venture projects were formed, earning the students 361 national prizes and 969 provincial prizes in Hainan Province. In 2017, the university was nominated as one of the 30 top universities in terms of the entrepreneurial education indicators in Southern China. In December the same year, the university participated in the Second Annual Meeting of Innovation and Entrepreneurship of University Students in Hainan Province with the First Cultural Festival of Innovation and Entrepreneurship of Universities in Hainan Province. A total of 15 theses and 20 venture projects were selected in the event, and 14 teachers were selected to be among the first 10,000 outstanding innovation and entrepreneurship teachers in China. This demonstrated the university's excellence in entrepreneurial education. Therefore, the selected participants were a representative sample.

\subsection{Research Instruments}

The entrepreneurial self-efficacy, perceived social support, and entrepreneurial intention scales employed by this study are detailed as follows:

(1) Entrepreneurial Self-Efficacy Scale

The employed entrepreneurial self-efficacy scale was devised by Niu (2017). The 
scale contains four dimensions and 16 items and adopts a 5 -point scale $(1=$ strongly disagree; 5 = strongly agree). With a Cronbach's a of 0.929 and cumulative total explained variance of $67.459 \%$, this scale exhibited satisfactory reliability and validity.

(2) Perceived Social Support Scale

The perceived social support scale was devised by Yan and Zheng (2006). The scale consists of three dimensions and 12 items and adopts a 5-point scale $(1=$ strongly disagree; 5 = strongly agree). With a Cronbach's a of 0.905 and cumulative total explained variance of $69.916 \%$, this scale exhibited satisfactory reliability and validity.

(3) Entrepreneurial Intention Scale

The entrepreneurial intention scale was created by Liñán and Chen (2009), consisting of one dimension and six items and adopting a 5-point scale $(1=$ strongly disagree; 5 = strongly agree); a high score indicated a strong entrepreneurial intention. With a Cronbach's a of 0.919 and cumulative total explained variance of $71.380 \%$, this scale exhibited satisfactory reliability and validity.

\subsection{Statistical Analysis Method}

SPSS Statistics 22.0 was employed to analyze the collected data through descriptive statistics, Pearson product-moment correlation, and regression analysis.

\section{Results}

The following is an analysis of the descriptive statistics of the participants, variable descriptive statistics and correlation analysis, the predictive power of entrepreneurial self-efficacy to entrepreneurial intentions, and the moderating effect of social support on the relationship between entrepreneurial self-efficacy and entrepreneurial intentions.

\subsection{Descriptive Statistics of the Participants}

A total of 900 questionnaires were distributed and returned; 870 were valid for a valid return rate of $96.6 \%$. Among the participants, 209 were men $(37 \%)$ and 548 were women (63\%); 177 were first-year university students $(20.3 \%), 277$ were second-year students (31.8\%), 277 were third-year students $(31.8 \%)$, and 139 were fourth-year students (16\%); 218 majored in humanities (25.1\%), 103 in science and engineering (11.8\%), 60 in arts (6.9\%), 155 in sports $(17.8 \%), 148$ in hotel management $(17 \%), 86$ in business $(9.9 \%)$, and 100 in foreign languages $(11.5 \%)$. 


\subsection{Variable Descriptive Statistics and Correlation Analysis}

As shown in Table 1, the mean (M) and standard deviation (SD) of each variable are as follows: entrepreneurial self-efficacy $(\mathrm{M}=3.433$ and $\mathrm{SD}=0.550)$, social support $(\mathrm{M}=3.658$ and $\mathrm{SD}=0.598)$, and entrepreneurial intentions $(\mathrm{M}=3.141$ and $\mathrm{SD}=0.810)$. Because all three scales were rated on 5-point scales, they all exhibited moderate-to-high average scores. A significant and positive correlation was found between all variables, namely between entrepreneurial self-efficacy and social support $(\mathrm{r}=0.477 ; p<.01)$, between entrepreneurial self-efficacy and entrepreneurial intentions $(r=0.632 ; p<.01)$, and between social support and entrepreneurial intentions $(\mathrm{r}=0.305 ; p<.01)$. The correlation coefficient of each pair was $0.305-0.632$, indicating no collinearity.

Table 1. Variable descriptive statistics and correlation analysis

\begin{tabular}{lccccc}
\hline \multicolumn{1}{c}{ Variable } & M & SD & $\begin{array}{c}\text { Entrepreneurial } \\
\text { Self-efficacy }\end{array}$ & $\begin{array}{c}\text { Social } \\
\text { Support }\end{array}$ & $\begin{array}{c}\text { Entrepreneuri } \\
\text { al Intentions }\end{array}$ \\
\hline Entrepreneurial & 3.433 & 0.550 & 1 & & \\
Self-efficacy & 3.658 & 0.598 & $0.477^{\star *}$ & 1 & \\
Social Support & 3.141 & 0.810 & $0.632^{\star *}$ & $0.305^{* *}$ & 1 \\
Entrepreneurial Intentions & & & & & \\
\hline
\end{tabular}

${ }^{*} \mathrm{p}<0.05,{ }^{* *} \mathrm{p}<0.01,{ }^{* * *} \mathrm{p}<0.001$

\subsection{Predictive Power of Entrepreneurial Self-Efficacy to Entrepreneurial Intentions}

According to Table 2, the $\mathrm{F}$ and $\beta$ values of Model 1 are $61.503(p<.001)$ and $0.588(p<.001)$, respectively, and the explained variance is $44.1 \%$. This indicated that the entrepreneurial self-efficacy of the participants significantly and positively predicted entrepreneurial intentions. Thus, H1 was supported.

\subsection{Moderating Effect of Social Support on the Relationship between Entrepreneurial Self-Efficacy and Entrepreneurial Intentions}

Hierarchical multiple regression analysis was conducted on the moderating effect of social support on the relationship between entrepreneurial self-efficacy and entrepreneurial intentions with the demographic information of the participants (e.g., sex, grade, and major) controlled. Entrepreneurial self-efficacy and social support were standardized to prevent collinearity. As shown in Table 2 , the variance inflation factors of all variables are $<10$, indicating that no collinearity existed between the variables. The F value of Model 3 was 52.592 ( $p$ $<.001)$. The interaction between entrepreneurial self-efficacy and social support was significant $(\beta=0.051, p<.05)$, indicating that social support positively moderated the relationship between entrepreneurial self-efficacy and 
entrepreneurial intentions. Thus, $\mathrm{H} 2$ was supported.

Table 2. Hierarchical multiple regression analysis of the moderating effect of social support on the relationship between entrepreneurial self-efficacy and entrepreneurial intentions

\begin{tabular}{|c|c|c|c|c|c|}
\hline Variable & & Model 1 & Model 2 & Model 3 & VIF \\
\hline Sex (Male) & & $0.066^{*+\alpha}$ & $0.070^{\text {*w }}$ & $0.068^{*}$ & 1.304 \\
\hline Grade (2nd) & & $0.106^{\text {wat }}$ & $0.107^{* *}$ & $0.110^{* *}$ & 2.350 \\
\hline Grade (3rd) & & 0.054 & 0.056 & 0.056 & 2.225 \\
\hline Grade (4th) & & 0.004 & 0.005 & 0.006 & 1.696 \\
\hline Major (Science \& Engineering) & & $0.072^{\text {wat }}$ & $0.073^{* *}$ & $0.073^{*}$ & 1.387 \\
\hline Major (Arts) & & $0.135^{\text {wat }}$ & $0.137^{*+k}$ & $0.138^{*}$ & 1.420 \\
\hline Major (Sports) & & $0.194^{\text {wat }}$ & $0.194^{*+x^{*}}$ & $0.194^{\text {wat }}$ & 1.761 \\
\hline Major (Hotel Management) & & $0.081^{* *}$ & $0.083^{\text {*k }}$ & $0.081^{* *}$ & 1.448 \\
\hline Major (Business) & & 0.057 & $0.058^{*}$ & $0.058^{*}$ & 1.309 \\
\hline Major (Foreign Languages) & & 0.019 & 0.200 & 0.019 & 1.330 \\
\hline Entrepreneurial Self-Efficacy & & $0.588^{\text {sov }}$ & $0.574^{* w+}$ & $0.571^{\text {wat }}$ & 1.442 \\
\hline Social Support & & & 0.027 & 0.029 & 1.340 \\
\hline $\begin{array}{l}\text { Entrepreneurial Self-Efficacy } \\
\text { Support }\end{array}$ & $\times \quad$ Social & & & $0.051^{*}$ & 1.010 \\
\hline $\mathrm{R}^{2}$ & & $44.1 \%$ & $44.1 \%$ & $44.4 \%$ & \\
\hline Adj R ${ }^{2}$ & & $43.4 \%$ & $43.4 \%$ & $43.6 \%$ & \\
\hline $\mathrm{F}$ & & $61.503^{\text {wex }}$ & $56.441^{* *}$ & $52.592^{* * * 4}$ & \\
\hline
\end{tabular}

${ }^{*} p<0.05,{ }^{* *} p<0.01,{ }^{* * *} p<0.001$

Reference group: Sex (Female), Grade (1st), Major (Humanities)

As depicted in Figure 2, social support reinforced the relationship between entrepreneurial self-efficacy and entrepreneurial intentions. Specifically, the participants with higher social support exhibited a stronger relationship between entrepreneurial self-efficacy and entrepreneurial intentions compared with their counterparts with lower social support. 


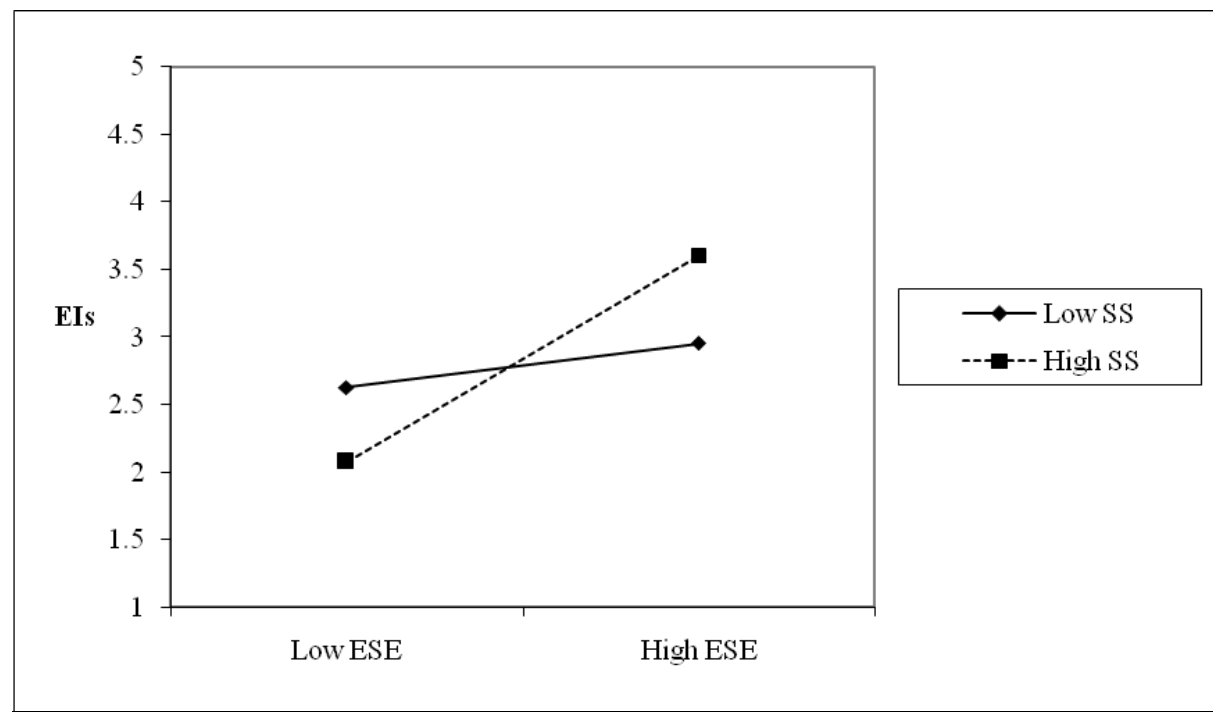

EIs = Entrepreneurial Intentions

$\mathrm{ESE}=$ Entrepreneurial Self-efficacy

SS $=$ Social Support

Figure 2. Moderating effect of social support on the relationship between entrepreneurial self-efficacy and entrepreneurial intentions.

\section{Discussion}

The following will discuss and conclude respectively according to the analysis results of this study.

\subsection{Entrepreneurial Self-Efficacy Positively Predicted Entrepreneurial intentions}

The research results indicated that entrepreneurial self-efficacy positively predicted entrepreneurial intentions, implying that university students with higher entrepreneurial self-efficacy exhibited higher entrepreneurial intentions; this was consistent with the findings of Urban (2006) and Qiao and Huang (2019). According to Zhao et al. (2005), individuals with higher entrepreneurial self-efficacy are more confident in their entrepreneurial capabilities, and thus, are more likely to enter into entrepreneurship. Accordingly, university students with higher entrepreneurial self-efficacy are more confident in their capability to conduct successful entrepreneurship, and thus exhibit stronger entrepreneurial intentions.

\subsection{Social Support Positively Moderated the Effect of Entrepreneurial Self-Efficacy on Entrepreneurial Intentions}

The research results indicated that social support positively moderated the effect of entrepreneurial self-efficacy on entrepreneurial intentions, which was consistent with the findings of Abebe et al. (2014). The present study suggested that, because social support provides material and spiritual support to 
entrepreneurs, university students who received social support showed enhanced confidence and determination in entrepreneurship and strong entrepreneurial intentions. According to the triadic reciprocal determinism of Bandura (1977), the relationships and influence among individual, environmental, and behavioral factors are a process of interactive determination. The interactions of behavioral factors with individual and environmental factors are a triadic interaction among the three. This study revealed that entrepreneurial self-efficacy (an individual factor) affected entrepreneurial intentions (behavioral factors) through its interaction with social support (an environmental factor) and that social support positively moderated the effect of entrepreneurial self-efficacy on entrepreneurial intentions, confirming the interaction among factors suggested in the triadic reciprocal determinism.

\section{Suggestions}

(1) Improve entrepreneurial self-efficacy of university students

According to the conclusion that entrepreneurial self-efficacy positively predicted entrepreneurial intentions, this study presented the following suggestions for universities and competent authorities:

Universities should host various entrepreneurship competitions and increase their number of entrepreneurship training courses. This would enable university students to identify their entrepreneurial specialties and directions, rather than limiting them to conceptual or theoretical understandings. Practical training should be provided to foster students' innovative thoughts, enabling them to think independently and properly respond to problems they encounter during entrepreneurship.

The government, universities, and enterprises must strengthen their collaboration in providing opportunities and conditions for entrepreneurial practices to university students, establishing funds to support university students' venture projects, and providing them with guarantees and services in terms of entrepreneurial information, training, and funds. If university students could have direct contact with the market and discover numerous entrepreneurial options, their entrepreneurial experience would be enriched and their abilities to recognize and seize entrepreneurial opportunities would be enhanced.

In addition, universities should actively invite alumni and successful entrepreneurs to exchange and share their experience of entrepreneurship and team management through forums. Furthermore, universities should incorporate interpersonal interactions and communications into daily education and disseminate knowledge on interpersonal interaction through social interaction courses or speeches. Various entrepreneurial student clubs can be 
initiated to strengthen students' interpersonal communication and nurture their coordination and management potential.

Moreover, universities should provide psychological counseling services for entrepreneurial students to strengthen their psychological health and stress responses, thereby enabling them to rationally navigate entrepreneurial pressure and risks. To fully prepare themselves for entrepreneurship, university students should also strengthen their own psychological qualities, foster their active and proactive characteristics, cultivate their observation and analysis skills, pay close attention to the business and environmental changes that occur during entrepreneurship, and overcome the obstacles, failure, and self-doubt encountered during entrepreneurship.

(2) Strengthen social support of university students

According to the conclusion that social support positively moderated the effect of entrepreneurial self-efficacy on entrepreneurial intentions, this study presented the following suggestions:

Families should provide university students with the basic funds required for entrepreneurship, thereby relieving them of material pressure. Furthermore, families should provide these students with spiritual support to enable them to perceive selfless help and support; this would enhance their entrepreneurial self-efficacy and hence increase entrepreneurial intentions. Friends, teachers, classmates, and relatives should also provide students with positive support. When university students encounter difficulties, care and consolation should be provided to help them overcome difficulties in active entrepreneurship. Such positive support from their friends, teachers, classmates, and relatives will university students' confidence in entrepreneurship. University students with high social support are able to respond calmly to difficulties in entrepreneurship and actively seek support from others, which reinforces their self-confidence in entrepreneurship and thus facilitates successful entrepreneurship.

\section{Research Limitations and Future Directions}

This study had some limitations regarding samples and the distribution of questionnaires. Future studies can broaden their sample range by investigating students from different countries and regions. Moreover, qualitative research should be conducted to enrich the research results. Future studies should explore the moderating effect of other variables on the relationship between entrepreneurial self-efficacy and entrepreneurial intentions for more extensive results and discussions. 


\section{References}

Abebe, M. A., Gangadharan, A., \& Sutanonpaiboon, J. (2014). Perceived social support and social status as drivers of entrepreneurial career intentions between Caucasian and Mexican-American young adults. Journal of Entrepreneurship Education, 17, 63-81. Retrieved from https://sbe.sonoma.edu/research/perceived-social-support-and-social-status-d rivers-entrepreneurial-career-intentions

Bandura, A. (1977). Self-efficacy: Toward a unifying theory of behavioral change. Psychological Review, 84(2), 191-215. Retrieved from http:/ /dx.doi.org/10.1037/0033-295X.84.2.191

Bandura, A. (1989). Human agency in social cognitive theory. American Psychologist, 44(9), 1175-1184. Retrieved from http:/ / dx.doi.org/10.1037/0003-066X.44.9.1175

Barral, M. R. M., Ribeiro, F. G., \& Canever, M. D. (2018). Influence of the university environment in the entrepreneurial intention in public and private universities. RAUSP Management Journal, 53(1), 122-133. Retrieved from https://doi.org/10.1016/j.rauspm.2017.12.009

Barrera, M. (1986). Distinctions between social support concepts, measures, and models. American Journal of Community Psychology, 14(4), 413-445. Retrieved from https:// doi.org/10.1007/BF00922627

Bird, B. (1988). Implementing entrepreneurial ideas: The case for intention. Academy of Management Review, 13(3), 442-453. Retrieved from https:// doi.org/10.2307/258091

Bosma, N., Acs, Z., Autio, E., Coduras, A., \& Levie, J. (2009). Global entrepreneurship monitor, 2008 executive report. Wellesley, MA: Babson College.

Boyd, N. G., \& Vozikis, G. S. (1994). The influence of self-efficacy on the development of entrepreneurial intentions and actions. Entrepreneurship Theory and Practice, 18(4), 63-77. Retrieved from https:/ / doi.org/10.1177/104225879401800404

Brice, J., Jr., \& Spencer, B. (2007). Entrepreneurial profiling: A decision policy analysis of the influence of entrepreneurial self-efficacy on entrepreneurial intent. Academy of Entrepreneurship Journal, 13(2), 47-67. Retrieved from https://www.researchgate.net/publication/284378853_Entrepreneurial_profilin g_A_decision_policy_analysis_of_the_influence_of_entrepreneurial_self-efficacy _on_entrepreneurial_intent

Carland, J. W., Hoy, F., Boulton, W. R., \& Carland, J. A. C. (1984). Differentiating entrepreneurs from small business owners: A conceptualization. Academy of Management Review, 9(2), 354-359. Retrieved from https:// doi.org/10.2307/258448

Chen, C. C., Greene, P. G., \& Crick, A. (1998). Does entrepreneurial self-efficacy distinguish entrepreneurs from managers? Journal of Business Venturing, 13(4), 295-316. Retrieved from https:/ / doi.org/10.1016/S0883-9026(97)00029-3

Cobb, S. (1976). Social support as a moderator of life stress. Psychosomatic Medicine, 38(5), 300-314. Retrieved from http:/ /dx.doi.org/10.1097/00006842-197609000-00003

Coduras, A., Urbano, D., Rojas, Á., \& Martínez, S. (2008). The relationship between university support to entrepreneurship with entrepreneurial activity in spain: a gem data based analysis. International Advances in Economic Research, 14(4), 395-406. Retrieved from https://doi.org/10.1007/s11294-008-9173-8

Cohen, S., \& McKay, G. (1984). Social support, stress and the buffering hypothesis: A theoretical analysis. In A. Baum \& J. E. Singer (Eds.), Handbook of psychology and health (Vol. 4, pp. 253-267). Hillsdale, NJ: Lawrence Erlbaum Associates.

Engel, Y., Dimitrova, N. G., Khapova, S. N., \& Elfring, T. (2014). Uncertain but able: Entrepreneurial self-efficacy and novices' use of expert decision-logic under uncertainty. Journal of Business Venturing Insights, 1, 12-17. Retrieved from https://doi.org/10.1016/j.jbvi.2014.09.002 
Fan, W., \& Wang, Z. M. (2004). The study of entrepreneurial intention and its determinants. PSYCHOLOGICAL SCIENCE-SHANGHAI-, 27(5; ISSU 151), 1087-1090. Retrieved from https://doi.org/10.16719/j.cnki.1671-6981.2004.05.016

Fishbein, M., \& Ajzen, I. (1975). Belief, attitude, intention, and behaviour: An introduction to theory and research. Reading, MA: Addison-Wesley.

Forbes, D. P. (2005). The effects of strategic decision making on entrepreneurial self-efficacy. Entrepreneurship Theory and Practice, 29(5), 599-626. Retrieved from https://doi.org/10.1111/j.1540-6520.2005.00100.x

Gelard, P., \& Saleh, K. E. (2011). Impact of some contextual factors on entrepreneurial intention of university students. African Journal of Business Management, 5(26), 10707-10717. Retrieved from https://doi.org/10.5897/ AJBM10.891

Han, L. Z., \& Fu, H. (2009). The development of a measuring scale for undergraduates' self-efficacy in starting an undertaking. Journal of Nanjing Normal University (Social Science Edition), 2009, 113-118. Retrieved from http:/ /en.cnki.com.cn/ Article_en/CJFDTOTAL-NJSS200901021.htm

Katz, J. A., Hanke, R., Maidment, F., Weaver, K. M., \& Alpi, S. (2016). Proposal for two model undergraduate curricula in entrepreneurship. International Entrepreneurship and Management Journal, 12(2), 487-506. Retrieved from https:/ / doi.org/10.1007/s11365-014-0349-9

Kickul, J., Gundry, L. K., Barbosa, S. D., \& Whitcanack, L. (2009). Intuition versus analysis? Testing differential models of cognitive style on entrepreneurial self-efficacy and the new venture creation process. Entrepreneurship Theory and Practice, 33(2), 439-453. Retrieved from https://doi.org/10.1111/j.1540-6520.2009.00298.x

Krueger, N. (1993). The impact of prior entrepreneurial exposure on perceptions of new venture feasibility and desirability. Entrepreneurship Theory and Practice, 18(1), 5-21. Retrieved from https://doi.org/10.1177/104225879301800101

Krueger, N. F., Jr., \& Brazeal, D. V. (1994). Entrepreneurial potential and potential entrepreneurs. Entrepreneurship Theory and Practice, 18(3), 91-104. Retrieved from https:/ / doi.org/10.1177/104225879401800307

Lee, S. T., Lee, H. K., Ki, H. S., \& Gim, G. Y. (2018). An influence on online entrepreneurship education platform utilization and self-deterministic to college students' entrepreneurial intention. International Conference on Computer and Information Science (pp. 189-211). Cham: Springer.

Liao, J., \& Welsch, H. (2003). Social capital and entrepreneurial growth aspiration: A comparison of technology-and non-technology-based nascent entrepreneurs. The Journal of High Technology Management Research, 14(1), 149-170. Retrieved from https://doi.org/10.1016/S1047-8310(03)00009-9

Liñán, F., \& Chen, Y. W. (2009). Development and cross - cultural application of a specific instrument to measure entrepreneurial intentions. Entrepreneurship Theory and Practice, 33(3), 593-617. Retrieved from https:/ / doi.org/10.1111/j.1540-6520.2009.00318.x

Lumpkin, G. T., \& Dess, G. G. (2001). Linking two dimensions of entrepreneurial orientation to firm performance: The moderating role of environment and industry life cycle. Journal of Business Venturing, 16(5), 429-451. Retrieved from https://doi.org/10.1016/S0883-9026(00)00048-3

Lüthje, C., \& Franke, N. (2003). The 'making' of an entrepreneur: Testing a model of entrepreneurial intent among engineering students at MIT. RED Management, 33(2), 135-147. Retrieved from https://doi.org/10.1111/1467-9310.00288

Malecki, C. K., \& Demaray, M. K. (2002). Measuring perceived social support: Development of the child and adolescent social support scale (CASSS). Psychology in the Schools, 39(1), 1-18. Retrieved from 
http://dx.doi.org/10.1002/pits.10004

Mintzberg, H. (1973). Strategy-making in three modes. California Management Review, 16(2), 44-53. Retrieved from https:// doi.org/10.2307/41164491

Naktiyok, A., Karabey, C. N., \& Gulluce, A. C. (2010). Entrepreneurial self-efficacy and entrepreneurial intention: the Turkish case. International Entrepreneurship and Management Journal, 6(4), 419-435. Retrieved from https://doi.org/10.1007/s11365-009-0123-6

Nasiru, A., Keat, O. Y., \& Bhatti, M. A. (2015). Influence of perceived university support, perceived effective entrepreneurship education, perceived creativity disposition, entrepreneurial passion for inventing and founding on entrepreneurial intention. Mediterranean Journal of Social Sciences, 6(3), 88-95. Retrieved from https://doi.org/10.5901/mjss.2015.v6n3p88

Newman, A., Obschonka, M., Schwarz, S., Cohen, M., \& Nielsen, I. (2018). Entrepreneurial self-efficacy: A systematic review of the literature on its antecedents and outcomes, and an agenda for future research. Journal of Vocational Behavior, 110(B), 403-419. Retrieved from https:// doi.org/10.1016/j.jvb.2018.05.012

Niu, X. M. (2017). A study on the relationship between college students' social network, entrepreneurial self-efficacy and entrepreneurial intention (Master degree thesis). Southwest Jiaotong University, Chongqing.

Oftedal, E. M., Iakovleva, T. A., \& Foss, L. (2018). University context matter: An institutional perspective on entrepreneurial intentions of students. Education + Training, 60(7/8), 873-890. Retrieved from https://doi.org/10.1108/ET-06-2016-0098

Passaro, R., Quinto, I., \& Thomas, A. (2018). The impact of higher education on entrepreneurial intention and human capital. Journal of Intellectual Capital, 19(1), 135-156. Retrieved from https:// doi.org/10.1108/JIC-04-2017-0056

Phan, P. H., Wong, P. K., \& Wang, C. K. (2002). Antecedents to entrepreneurship among university students in Singapore: Beliefs, attitudes and background. Journal of Enterprising Culture, 10(2), 151-174. Retrieved from https://doi.org/10.1142/S0218495802000189

Qiao, X., \& Huang, J. H. (2019). Effect of College Students' Entrepreneurial Self-Efficacy on Entrepreneurial Intention: Career Adaptability as a Mediating Variable. International Journal of Educational Methodology, 5(3), 305-313. Retrieved from https:/ / doi.org/10.12973/ijem.5.3.305

Sarason, I. G., \& Johnson, J. H. (1981). A technical report. Washington, DC: University of Washington.

Shan, S., Jia, Y., Zheng, X., \& Xu, X. (2018). Assessing relationship and contribution of China's technological entrepreneurship to socio-economic development. Technological Forecasting and Social Change, 135(October), 83-90. Retrieved from https://doi.org/10.1016/j.techfore.2017.12.022

Shiri, N., Mohammadi, D., \& Hosseini, S. M. (2012). Entrepreneurial intention of agricultural students: effects of role model, social support, social norms and perceived desirability. Archives of Applied Science Research, 4(2), 892-897.

Sun, Y., Zhang, D., Yang, Y., Wu, M., Xie, H., Zhang, J., ... Su, Y. (2017). Social support moderates the effects of self-esteem and depression on quality of life among Chinese rural elderly in nursing homes. Archives of Psychiatric Nursing, 31, 197-204. Retrieved from https://doi.org/10.1016/j.apnu.2016.09.015

Thoits, P. A. (1986). Social support as coping assistance. Journal of Consulting and Clinical Psychology, 54(4), 416-423. Retrieved from http://dx.doi.org/10.1037/0022-006X.54.4.416

Thompson, P., Jones-Evans, D., \& Kwong, C. (2009). Women and home-based entrepreneurship: Evidence from the United Kingdom. International Small 
Business Journal, 27(2), 227-239. Retrieved from https://doi.org/10.1177/0266242608100492

Urban, B. (2006). Entrepreneurship in the rainbow nation: Effect of cultural values and ESE on intentions. Journal of Developmental Entrepreneurship, 11(3), 171-186. Retrieved from http://dx.doi.org/10.1142/S1084946706000386

Viseu, J., Leal, R., de Jesus, S. N., Pinto, P., Pechorro, P., \& Greenglass, E. (2018). Relationship between economic stress factors and stress, anxiety, and depression: Moderating role of social support. Psychiatry Research, 268(October), 102-107. Retrieved from http://dx.doi.org/10.1016/j.psychres.2018.07.008

Xu, B. H., Wang, Y. G., \& Li, Y. M. (2013). The moderating effects of social support on relationship between job stress and job burnout among teachers in vocational colleges. Zhejiang Preventive Medicine, 25, 1-3. Retrieved from http://dx.doi.org/10.19485/j.cnki.issn1007-0931.2013.09.001

Yan, B., \& Zheng, X. (2006). Researches into relations among social-support, self-esteem and subjective well-being of college students. Psychology Development and Education, 22, 60-64. Retrieved from http://dx.doi.org/10.16187/j.cnki.issn1001-4918.2006.03.011

Zhao, H., Seibert, S. E., \& Hills, G. E. (2005). The mediating role of self-efficacy in the development of entrepreneurial intentions. Journal of Applied Psychology, 90(6), 267-296. Retrieved from http://dx.doi.org/10.1037/0021-9010.90.6.1265

Zimet, G. D., Dahlem, N. W., Zimet, S. G., \& Farley, G. K. (1988). The multidimensional scale of perceived social support. Journal of Personality Assessment, 52(1), 30-41. 